\title{
LIVELIHOOD RESILIENCE OF VEGETABLE FARMERS: EFFICACY OF ORGANIC FARMING IN DEALING WITH CLIMATE CHANGE IN JAVA, INDONESIA
}

\author{
FACHRISTA, I. A. ${ }^{1,2}-$ IRHAM $^{3 *}-$ MASYHURI $^{3}-$ SURYANTINI, A. $^{3}$ \\ ${ }^{1}$ Assessment Institute for Agricultural Technology of Bangka Belitung, Indonesian Agency for \\ Agricultural Research and Development Ministry of Agriculture, Jakarta, Indonesia \\ ${ }^{2}$ Faculty of Agriculture, Universitas Gadjah Mada, Indonesia \\ ${ }^{3}$ Department of Agricultural Socio-Economics, Faculty of Agriculture, Universitas Gadjah \\ Mada, Yogyakarta, Indonesia \\ *Corresponding author \\ e-mail:irham@ugm.ac.id
}

(Received 6 ${ }^{\text {th }}$ Apr 2019; accepted $2^{\text {nd }}$ Jul 2019)

\begin{abstract}
Some researchers believe that organic farming can improving farmer's resilience in dealing with climate change. Livelihood resilience is attributed to buffer capacity, self-organization, and learning capacity. Therefore, this study aims to 1) compare buffer capacity, self-organization, and learning capacity between organic and conventional farmers, 2) compare the level of livelihood resilience between organic and conventional farmers, and 3) know important determinants that influence the livelihood resilience of farmers in the face of climate change. Data were obtained through a survey involving 112 organic farmers and 112 conventional farmers in Java, Indonesia. The t-test was used to find out the buffer capacity, self-organization and learning capacity and livelihood resilience of farmers in the face of climate change. Ordinary least square was used to find out important determinants that influence the livelihood resilience level of farmers. The analysis shows that buffer capacity and learning capacity of organic farmers are better than that of the conventional farmers. Organic farmers have better livelihood resilience than conventional farmers. Important determinants that influence the farmer's level of resilience are cooperation networks, adaptation strategies and accessibility to extension services, and climate information and training. The study recommends that policymakers need to develop organic farming and supporting institutions to increase farmer's resilience in dealing with climate change.
\end{abstract}

Keywords: buffer capacity, learning capacity, self-organization, adaptation, vegetable farming

\section{Introduction}

Recent climate change has adversely affected horticultural crops (Haryono and Las, 2011; Rejekiningrum et al., 2011; Surmaini et al., 2011). The various negative impacts of climate change on horticulture crops, especially vegetables, include crop failure, decreased quantity, decreased product quality, increasing number of pest attack and plant disease problems, thus making farmers at risk of unprofitable vegetable cultivation (Ayyogari et al., 2014). Reports have been made on the negative impacts of climate change on vegetable crops in Indonesia that include extreme rainfall damaging vegetable crops and decreasing agricultural production, which may eventually lead to crop failure. In addition, it was reported that extreme rain throughout 2010 caused several vegetable productions in Indonesia to decrease by $20-25 \%$ (Rejekiningrum et al., 2011).

On this account, it is noteworthy that organic farming plays a significant role in dealing with climate change. Organic farming will have higher resilience than 
conventional farming (Jacobi et al., 2015). As a result, farmers with a better level of resilience will be more capable at maintaining and improving their livelihood and welfare opportunities since they are more adjustable to facing climate change disruptions. In the face of climate change, it is necessary to integrate resilience and livelihood because climate change will affect human livelihoods at greater intensity (Tanner et al., 2015). The approach on livelihood focuses on interactions between the livelihood context, livelihood assets, institutions, livelihood strategies, and the impact of livelihoods. Meanwhile, livelihood resilience in the face of climate change is characterized by a strategy carried out by actors to maintain and enhance their assets (Speranza et al., 2014).

Farmer's resilience in dealing with climate change varies between regions. There have been several studies to address the level of farmer's resilience in the face of climate change conducted in developing countries (e.g., Lal, 2014; Marseva et al., 2016; Tambo, 2016). In the face of climate change, most farmers' resilience levels are classified into the weak to moderate categories, such as farmers in Nepal (Lal, 2014) and farmers in northeast Ghana (Tambo, 2016). The research conducted by Marseva et al. (2016), also showed that in Central Java, Indonesia, farmer's resilience in the face of climate change is still relatively low. Low resilience level in dealing with climate change is attributed to the low level of human, social and physical capital owned by farmers.

There are some dimensions of measuring the level of resilience to climate change used by researchers. Some dimension used to measure resilience include: 1) based on asset (e.g., Thulstrup, 2015), 2) based on six dimension of Resilience Index Measure and Analysis (RIMA) of the Food and Agriculture Organization of the United Nations, which include income and food access, access to basic services, assets, social safety nets, stability, and adaptive capacity (e.g., FAO, 2016; Tambo, 2016; Tambo and Wünscher, 2017; Weldegebriel and Amphune, 2017). The measurement of resilience integrated with livelihoods, known as livelihood resilience, was put forward by Speranza et al. (2014). Livelihood resilience in the face of climate change is constituted of buffer capacity, self-organization, and learning capacity (Speranza et al., 2014).

As what the experts have put forward, organic farming is the right solution to increase the farmers' livelihood resilience in the face of climate change. However, there were only few researches to address the livelihood resilience of the farmers' in dealing with climate change despite its relevance to the current situation. Therefore, this study aims to 1) compare buffer capacity, self-organization, and learning capacity between organic and conventional farmers, 2) compare the level of livelihood resilience between organic and conventional farmers in dealing with climate change, and 3) know important determinant that affects the livelihood resilience of organic farmers and conventional in dealing with climate change.

\section{Materials and methods}

\section{Research location and sampling}

The research location was determined purposively in Java, especially in the Special Region of Yogyakarta and Central Java Province, considering that the two areas greatly develop organic vegetable cultivation. Some regencies of each province were selected for the research location, namely Sleman Regency (Special Region of Yogyakarta) and Magelang Regency, Boyolali Regency and Semarang Regency (Central Java) (Fig. 1). 


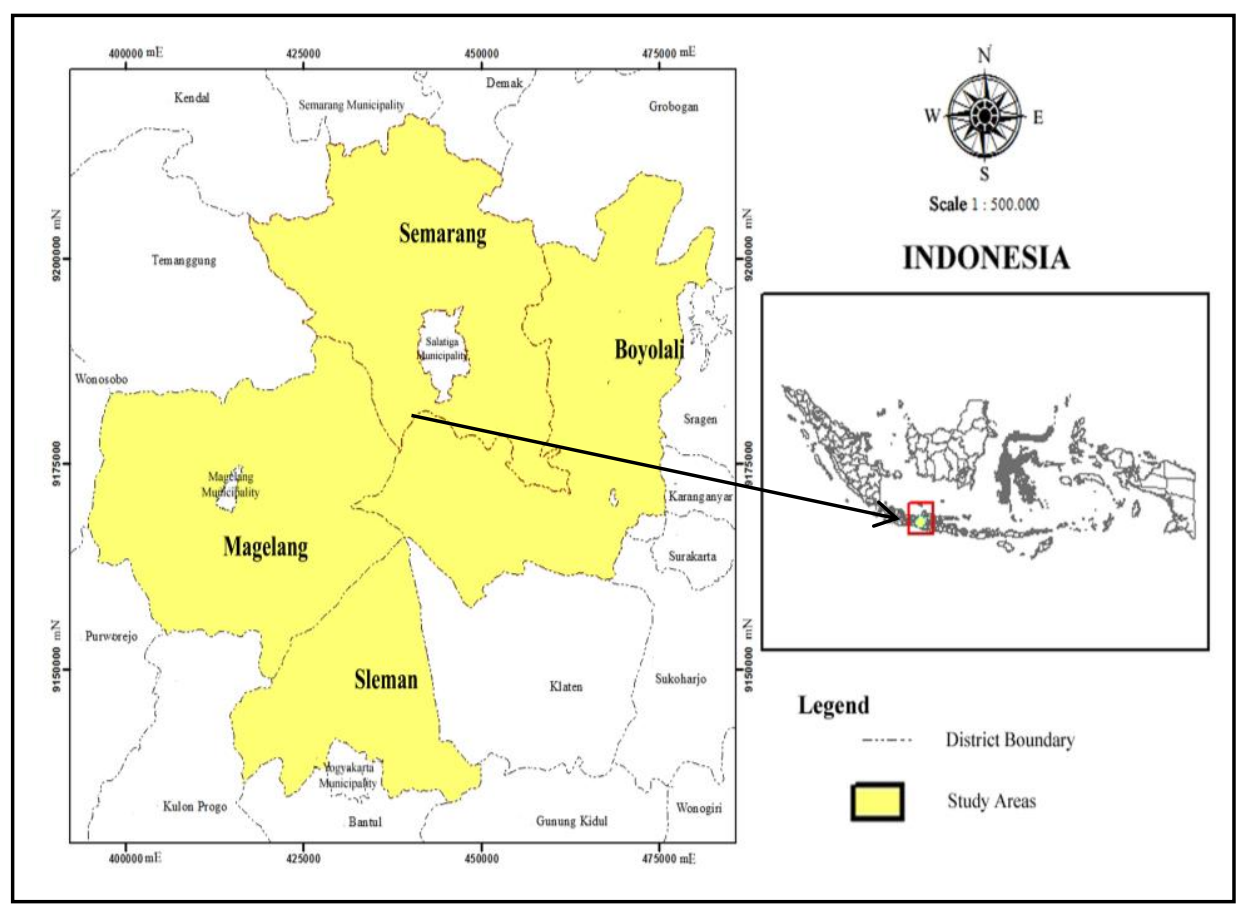

Figure 1. Study area

The survey was conducted in February - August 2018, by involving organic farmers and conventional farmers. Organic farmers selected by using proportionate random sampling method (Table 1).

Table 1. Population and sample of organic farmers

\begin{tabular}{c|c|c}
\hline Regency & Population & Sample \\
\hline Sleman & 30 & 22 \\
Magelang & 24 & 17 \\
Boyolali & 25 & 18 \\
Semarang & 77 & 55 \\
\hline Total & 156 & 112 \\
\hline
\end{tabular}

The sample size based on Slovin's formula, is given as follows: $n=N /\left(1+\left(N \cdot e^{2}\right)\right.$, where $\mathrm{n}$ is the sample size, $\mathrm{N}$ is the population size and e is the margin of error (0.05). Therefore based on the formula, the sampling size in this research is 112 organic farmer, and as comparison, there are 112 conventional farmers. Conventional vegetable farmers are living nearby organic vegetable farmers with the consideration that both groups experience the negative impact of climate change and relatively have similar socioeconomic conditions.

The survey was conducted with a structured questionnaire guide. The first part of the questionnaire collects some background information such as age, household size, marketing network in selling crop yields with other parties, and accessibility to various institutions such as credit institutions, extension, access to information and climate training. The second part investigates adaptation strategies adopted by farmers to reduce 
the negative impact of climate change on vegetable farming. The last section addresses farmers' livelihood resilience in dealing with climate change. This study collected 224 questionnaires for analysis.

\section{Analytical methods}

\section{Data analysis}

Data were analyzed by t-test and ordinary least square (OLS) regression analysis. The t-test was used to compare buffer capacity, self-organization and learning capacity and the level of livelihood resilience between organic vegetable farmers and conventional vegetable farmers in the face of climate change. OLS was used to find out important determinants affecting the farmers' livelihood resilience index in dealing with climate change. Important determinants that affect farmers' livelihood resilience in dealing with climate change were selected based on the previous studies, such as age (Tesso et al., 2012; Weldegebriel and Amphune, 2017), household size (Weldegebriel and Amphune, 2017), engagement in trade (Weldegebriel and Amphune, 2017), and accessibility to various institutions such as credit institutions (Keil et al., 2008; Tesso et al., 2012), extension institutions (Tesso et al., 2012), information on climate change (Keil et al., 2008), climate training and the amount of adaptation that farmers have applied to deal with climate change (Tambo and Wünscher, 2017; Uy et al., 2011). The description of each variable used in this study is presented in Table 2.

Table 2. Description of variables

\begin{tabular}{|c|c|}
\hline Variable & Description of the variables \\
\hline Livelihood resilience & Livelihood resilience in the face of climate change (index) \\
\hline Age & Age of the head of the family in years \\
\hline Household size & Number of family members in the household \\
\hline Engagement in trade & Dummy $(1=$ if farmers have engagement in trade and $0=$ if otherwise) \\
\hline Access to credit & Dummy ( $1=$ if farmers have access to credit institutions and $0=$ if otherwise) \\
\hline Access to extension services & Dummy $(1=$ if farmers have access to extension services and $0=$ if otherwise) \\
\hline Access to climate information & Dummy ( $1=$ if farmers have access to climate information and $0=$ if otherwise) \\
\hline Access to climate training & Dummy $(1=$ if farmers have access to climate training and $0=$ if otherwise $)$ \\
\hline Number of adaptation strategies & The number of adaptation strategies applied by farmers in facing climate change \\
\hline
\end{tabular}

Adaptation strategies adopted by farmers to reduce the negative impacts of climate change were obtained from the previous research and preliminary information, namely implementing implementing mixed cropping (Abid et al., 2016; Fosu-Mensah et al., 2012; Ichdayanti, 2014), using superior varieties (Ali and Erenstein, 2017; Ichdayanti, 2014; Milambo, 2013; Ruminta, 2015; Tambo, 2016), growing non water-intensive vegetable (Ichdayanti, 2014), implementing crop rotation (Kurniawati, 2012), adjusting planting and harvesting dates (Ali and Erenstein, 2017; Deressa et al., 2009; FosuMensah et al., 2012), increasing the dose of organic matter (Irham et al., 2018; Makate et al., 2017), using mulch (Ichdayanti, 2014), using shade (Adiyoga and Lukman, 2018; Kurniawati, 2012), changing irrigation techniques (Abid et al., 2016; Tambo, 2016), using pranata mangsa a local technique based on regular natural events (initial information from farmer interviews). 
Table 3. Components, indicators, description and values of livelihood resilience in dealing with climate change

\begin{tabular}{|c|c|c|c|}
\hline Component & Indicators & Description & Units \\
\hline \multirow{13}{*}{$\begin{array}{l}\text { Buffer } \\
\text { capacity }\end{array}$} & \multirow{4}{*}{ Human capital } & Duration of education & Years \\
\hline & & Farming experience & Years \\
\hline & & Other skills besides farming & Count \\
\hline & & Number of sick family members & Count \\
\hline & \multirow{4}{*}{ Financial capital } & Annual revenue of vegetable farming & USD/ha \\
\hline & & Livestock saving & USD \\
\hline & & Annual labor income & USD/year \\
\hline & & $\begin{array}{c}\text { Dependency ratio: a ratio of members aged below } 15 \text { and } \\
\text { above } 64 \text { to those aged 15-64 }\end{array}$ & Ratio \\
\hline & \multirow{3}{*}{ Social capital } & Asset increase due to organization partnership & USD \\
\hline & & Support of workforce from the group & Man-days \\
\hline & & Use of group equipment & Count \\
\hline & Physical capital & Machinery, equipment, buildings, farming wells & USD \\
\hline & Natural capital & $\begin{array}{l}\text { Weighted averaged soil fertility of the land owned by } \\
\text { farmer }\end{array}$ & Index \\
\hline \multirow{3}{*}{$\begin{array}{l}\text { Self- } \\
\text { organization }\end{array}$} & $\begin{array}{l}\text { Cooperation and } \\
\text { network }\end{array}$ & Number of group organization followed by farmers & Count \\
\hline & Trust & $\begin{array}{l}\text { Trust between community members in lending and } \\
\text { borrowing funds }\end{array}$ & Percentage \\
\hline & $\begin{array}{l}\text { Reliance on own } \\
\text { resources }\end{array}$ & The closest distance needed to obtain farming inputs & Kilometer \\
\hline \multirow{12}{*}{$\begin{array}{l}\text { Learning } \\
\text { capacity }\end{array}$} & \multirow{2}{*}{$\begin{array}{c}\text { Knowledge of treat } \\
\text { and opportunities }\end{array}$} & $\begin{array}{c}\text { The ability to analyze threats to increase production over } \\
\text { the past } 12 \text { months }\end{array}$ & Count \\
\hline & & \begin{tabular}{|c|}
$\begin{array}{c}\text { Ability to analyze opportunities to increase production } \\
\text { over the past } 12 \text { months }\end{array}$ \\
\end{tabular} & Count \\
\hline & Shared vision & $\begin{array}{c}\text { Frequency of discussion on farming development over } \\
\text { the past } 12 \text { months }\end{array}$ & Count \\
\hline & \multirow{3}{*}{$\begin{array}{l}\text { Commitment to } \\
\text { learning }\end{array}$} & Frequency of regular meetings with counselors & Count \\
\hline & & $\begin{array}{l}\text { Discussion frequency on the previous farming } \\
\text { performance with counselors and other farmers }\end{array}$ & Count \\
\hline & & $\begin{array}{l}\text { Time allocated per month to find information on } \\
\text { technology }\end{array}$ & $\begin{array}{l}\text { Minute per } \\
\text { month }\end{array}$ \\
\hline & \multirow{6}{*}{$\begin{array}{l}\text { Knowledge } \\
\text { identification } \\
\text { capability- } \\
\text { monitoring }\end{array}$} & The best time to sell and buy the best product & Count \\
\hline & & $\begin{array}{c}\text { Frequency of consultation on planning agricultural } \\
\text { products sold }\end{array}$ & Count \\
\hline & & $\begin{array}{l}\text { The number of technological innovations to applied by } \\
\text { farmers in the upcoming planting season }\end{array}$ & Count \\
\hline & & $\begin{array}{l}\text { The number of technological innovations tested by } \\
\text { farmers in the last } 12 \text { months }\end{array}$ & Count \\
\hline & & \begin{tabular}{|c|}
$\begin{array}{c}\text { Number of technological innovations adopted by farmers } \\
\text { in the last } 12 \text { months }\end{array}$ \\
\end{tabular} & Count \\
\hline & & Number of technological innovations applied now & Count \\
\hline
\end{tabular}




\begin{tabular}{c|c|c|c}
\hline & $\begin{array}{c}\text { Frequency in discussing the problem of farming } \\
\text { production with other actors in the group }\end{array}$ & Count \\
\cline { 2 - 4 } $\begin{array}{c}\text { Knowledge sharing } \\
\text { capability }\end{array}$ & $\begin{array}{c}\text { Number of farmers given new information or methods by } \\
\text { respondent farmers }\end{array}$ & Count \\
\cline { 2 - 4 } $\begin{array}{c}\text { Knowledge transfer } \\
\text { capability }\end{array}$ & $\begin{array}{c}\text { The number of ideas that farmers learn from other } \\
\text { farmers and other actors }\end{array}$ & Count \\
\cline { 2 - 4 } & $\begin{array}{c}\text { Functioning } \\
\text { feedback } \\
\text { mechanism }\end{array}$ & $\begin{array}{c}\text { Frequency of interaction with officers related to business } \\
\text { production in groups }\end{array}$ & Count \\
\hline
\end{tabular}

\section{Measurement of livelihood resilience}

The livelihood resilience used in this study was adapted from Speranza et al. (2014), Murphy (2015), Wahyuni (2016) and based on the construction of this study. Components, indicators and measurements of farmers' livelihood resilience in dealing with climate change are presented in Table 3. Livelihood resilience consists of three components, namely buffer capacity, self-organization and learning capacity. Each component consists of several indicators that can represent livelihood resilience. The steps taken to measure the livelihood resilience index are:

\section{Normalization}

It is important to normalize each indicator to make it in the range of 0 to. 1. Normalization was done because indicators of livelihood resilience are measured on a different scale. The normalization methods were based on the Human Development Index method (UNDP, 2006). Some indicators show that if the indicator value increases, the livelihood resilience will decrease. On this basis, we use two normalization methods so that the increasing value of each indicator will increase livelihood resilience:

a) Indicators where higher values, which imply better resilience such as education time, farming experience, farming acceptance, were normalized using the following formula:

$$
\tau_{\text {norm }}=\frac{\tau_{i j}-\tau_{\min }}{\tau_{\max }-\tau_{\min }}
$$

b) Indicators with higher values, which imply lower resilience such as sick family members and dependency ratios, were normalized using the following formula:

$$
\tau_{\text {norm }}=\frac{\tau_{\min }-\tau_{\max }}{\tau_{\max }-\tau_{\min }}
$$

where:

$\begin{array}{ll}\tau_{\text {norm }} & =\text { the value of } \mathrm{j} \text { indicator is for normalized household } \\ \tau_{i j} & =\text { the value of } \mathrm{j} \text { indicator is for household } \mathrm{i}\end{array}$ 
$\begin{array}{lll}\tau_{\max } & = & \text { maximum value of sub-indicators for all households } \\ \tau_{\min } & =\quad \text { minimum value of sub-indicators for all households }\end{array}$

2. Measuring livelihood resilience index

After normalization, the researcher calculated the livelihood resilience index using the equal-weight approach. The equal-weight approach assumes that each indicator has the same contribution to the livelihood resilience index. Measurements using this method are based on the average normalized values (Gbetibouo et al., 2010; Tambo and Wünscher, 2017). The value of each indicator was then averaged to obtain the value of each of the three indicators. The compound value was averaged to obtain the overall value of the livelihood resilience index. The farmers' livelihood resilience index in dealing with climate change resulted in the ranges from 0 to 1.

\section{Result}

\section{Socioeconomic profile of farmers and adaptation to climate change}

The socioeconomic conditions of organic vegetable farmers are better than those of conventional farmers (Table 4). Organic vegetable farmers have better accessibility to credit institutions, extension service, and engagement in trade than conventional farmers. Organic farmers are also younger and have more household members than conventional farmers. Young farmers will easily accept the technology, which can be used to adapt to climate change and family members can help farmers in vegetable farming. Organic farmers also implement more adaptation strategies to reduce the impact of climate change on vegetable farmer.

Table 4. Socioeconomic profile of farmers and adaptation to climate change

\begin{tabular}{c|c|c|c|c|c|c}
\hline & \multicolumn{2}{|c|}{ Organic } & \multicolumn{2}{c|}{ Conventional } & \multicolumn{2}{c}{ Difference $^{\mathbf{a}}$} \\
\cline { 2 - 6 } & Mean & Std. Dev & Mean & Std. Dev & \multicolumn{2}{|c}{} \\
Age & 45.214 & 12.836 & 45.455 & 11.527 & -0.241 & \\
Household size & 4.125 & 1.330 & 3.866 & 1.212 & 0.259 & \\
Engagement in trade & 0.839 & 0.369 & 0.179 & 0.385 & 0.661 & $* * *$ \\
Access to credit & 0.321 & 0.469 & 0.143 & 0.352 & 0.179 & $* *$ \\
Access to extension services & 0.634 & 0.484 & 0.500 & 0.723 & 0.134 & $* *$ \\
Access to climate information & 0.554 & 0.499 & 0.500 & 0.502 & 0.054 & \\
Access to climate training & 0.107 & 0.311 & 0.080 & 0.273 & 0.027 & $* * *$ \\
Number of adaptation strategies & 6.295 & 1.257 & 5.598 & 1.423 & 0.696 & $*$ \\
\hline
\end{tabular}

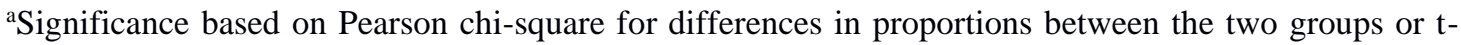
test for the average difference between the two groups. ${ }^{* * *}$ Significant at $1 \%$ level. ${ }^{* *}$ Significant at $5 \%$ level

\section{Buffer capacity, self-organization and learning capacity of organic and conventional farmers}

Table 5 presents the description and indicator values of the buffer capacity. The three indicators that greatly contribute to the buffer capacity of organic vegetable farmers and 
conventional vegetable farmers are natural capital, human capital and financial capital. This fact indicates that the three capitals play a significant role in increasing the buffer capacity of farmers. The significant difference from the indicators that compose the buffer capacity between organic vegetable farmers and conventional vegetable farmers lies in social capital, physical capital and natural capital. Organic farmers have higher social capital, physical capital and natural capital than conventional vegetable farmers. Organic vegetable farmers have higher social capital than conventional vegetable farmers because organic farmers get an increase in assets from group membership and support of the workforce from the group. Moreover, organic farmers also have better physical capital values as manifested through their ownership of machinery and other equipment. Natural capital such as soil fertility that owned by organic farmer higher than the conventional farmers.

On the other hand, organic vegetable farmers commonly have lower human capital and financial capital than conventional vegetable farmers. Table 5 shows that the human capital owned by organic vegetable farmers is lower than conventional vegetable farmers because organic farmers have shorter farming experience and have a greater number of dependents and sick families than conventional vegetable farmers, although the difference between organic and conventional is not statistically significant. Organic vegetable farmers also to have lower financial capital than conventional vegetable farmers, although the difference between organic and conventional is not statistically significant. Organic farmers have greater farming and labor income than conventional vegetable farmers, but organic farmers have a lower number of livestock savings and a higher level of dependency than conventional vegetable farmers. A higher level of dependency of organic farmer than conventional vegetable farmers because organic farmers have more family members than conventional farmers.

Table 5. Indicator values of buffer capacity component

\begin{tabular}{|c|c|c|c|c|}
\hline Indicators - description & Organic & Conventional & \multicolumn{2}{|c|}{ Difference $^{a}$} \\
\hline Human capital & 0.479 & 0.483 & -0.004 & \\
\hline Duration of education & 0.391 & 0.371 & 0.020 & \\
\hline Farming experience & 0.270 & 0.322 & -0.052 & \\
\hline Other skills besides farming & 0.281 & 0.249 & 0.032 & \\
\hline Number of sick family member & 0.973 & 0.991 & -0.018 & \\
\hline Financial capital & 0.279 & 0.285 & -0.006 & \\
\hline Annual income of vegetable farming & 0.283 & 0.174 & 0.109 & $* * *$ \\
\hline Livestock saving & 0.048 & 0.079 & -0.031 & $* *$ \\
\hline Annual labor income & 0.048 & 0.038 & 0.010 & \\
\hline Dependency ratio & 0.738 & 0.847 & -0.109 & $* * *$ \\
\hline Social capital & 0.046 & 0.024 & 0.022 & ** \\
\hline Asset increase due to organization partnership & 0.023 & 0.001 & 0.022 & $* *$ \\
\hline Support of workforce from the group & 0.063 & 0.022 & 0.041 & $* *$ \\
\hline Use of group equipment & 0.053 & 0.049 & 0.004 & \\
\hline Physical capital & 0.047 & 0.009 & 0.038 & ** \\
\hline Machinery, equipment, buildings, farming wells & 0.047 & 0.009 & 0.038 & $* *$ \\
\hline Natural capital & 0.751 & 0.617 & 0.134 & $* * *$ \\
\hline Weighted averaged soil fertility of the land owned by farmer & 0.751 & 0.617 & 0.134 & $* * *$ \\
\hline
\end{tabular}

${ }^{a}$ t-test for differences in the mean of two groups. ${ }^{* * *}$ Significant at level $1 \% .{ }^{* *}$ Significant at level $5 \%$ 
The indicator values of the self-organization components that make up the livelihood resilience index are presented in Table 6. Reliance on own resources owned by organic and conventional vegetable farmers contribute greatly to the value of self-organization, followed by trust and cooperation and network. Organic and conventional vegetable farmers do not have to travel far distance to obtain inputs. In addition, the people surrounding them also trust each other in terms of lending and borrowing. However, cooperation and network of organic vegetable farmers are higher than conventional farmers, since organic vegetable farmers have established a cooperation with other parties and have better participation in organizations than conventional vegetable farmers.

Table 6. Indicator values of the self-organization component

\begin{tabular}{c|c|c|c|c}
\hline Indicators - description & Organic & Conventional & \multicolumn{2}{|c}{ Difference $^{\mathrm{a}}$} \\
\hline Cooperation and network & 0.330 & 0.259 & 0.071 & $* *$ \\
Number of group organization followed by farmers & 0.330 & 0.259 & 0.071 & $* *$ \\
Trust & 0.593 & 0.566 & 0.027 & \\
Trust between community members in lending and borrowing funds & 0.330 & 0.259 & 0.071 & $* *$ \\
Reliance on own resources & 0.754 & 0.747 & 0.007 & \\
The closest distance needed to obtain farming inputs & 0.754 & 0.747 & 0.007 & \\
\hline
\end{tabular}

${ }^{a}$ t-test for different means of the two groups. ${ }^{* *}$ Significant at the $5 \%$ level

Table 7 presents the indicator values of the learning capacity component of conventional vegetable and organic vegetable farmers. Three indicators, namely knowledge of threat and opportunities, knowledge sharing capability, and knowledge identification capability of monitoring contribute to higher value than other indicators. This indicates that these indicators contribute highly to the learning capacity of organic and conventional vegetable farmers. Other indicators such as shared vision, commitment to learning, capability sharing and functioning feedback mechanism shared by organic and conventional vegetable farmers indicate a low value.

All description and indicator values of learning capacity of organic vegetable farmers are higher than those of conventional vegetable farmers (Table 7). Organic vegetable farmers have better knowledge at analyzing threats and opportunities, various visions, commitment to learning and knowledge of identification, knowledge sharing and transfer, as well as better feedback mechanism than conventional vegetable farmers. The significant difference in the indicator of the learning capacity component between organic vegetable farmers and conventional vegetable farmers lies in commitment to learning, knowledge of identification capability of monitoring, knowledge sharing capability, knowledge transfer capability, and feedback mechanism function. This indicates that organic vegetable farmers have more regular meetings with extension workers, and allocated time per month to find information on technology. Organic farmers also know better the best time to sell and buy products that conventional farmers. Furthermore, organic farmers have applied, adopted, and plan to used more technology, better ability in providing and receiving information from other actors, and more frequency of interactions with officers related to business production in groups than conventional vegetable farmers. 
Table 7. Indicator values of the learning capacity component

\begin{tabular}{|c|c|c|c|c|}
\hline \multirow{2}{*}{$\begin{array}{c}\text { Indicators - description } \\
\text { Knowledge of treat and opportunities }\end{array}$} & \multirow{2}{*}{\begin{tabular}{|c|} 
Organic \\
0.593
\end{tabular}} & \multirow{2}{*}{$\frac{\text { Conventional }}{0.566}$} & \multicolumn{2}{|c|}{ Difference $^{\mathrm{a}}$} \\
\hline & & & 0.027 & \\
\hline The ability to analyze threats & 0.459 & 0.458 & 0.001 & \\
\hline Ability to analyze opportunities & 0.727 & 0.673 & 0.054 & $*$ \\
\hline Shared vision & 0.099 & 0.074 & 0.025 & \\
\hline Frequency of discussion on farming development & 0.099 & 0.074 & 0.025 & \\
\hline Commitment to learning & 0.093 & 0.054 & 0.039 & $* *$ \\
\hline Frequency of regular meetings & 0.103 & 0.060 & 0.043 & $* *$ \\
\hline Discussion frequency on the previous farming performance & 0.101 & 0.079 & 0.022 & \\
\hline Time allocated per month to find information on technology & 0.076 & 0.025 & 0.051 & $* *$ \\
\hline Knowledge identification capability-monitoring & 0.237 & 0.089 & 0.148 & $* * *$ \\
\hline The best time to sell and buy the best product & 0.098 & 0.060 & 0.038 & $*$ \\
\hline Frequency of consultation on planning agricultural products & 0.670 & 0.321 & 0.349 & $* * *$ \\
\hline $\begin{array}{l}\text { The number of technological innovations to be applied by } \\
\text { farmers in the upcoming planting season }\end{array}$ & 0.065 & 0.016 & 0.049 & $* * *$ \\
\hline $\begin{array}{c}\text { The number of technological innovations tested by farmers in } \\
\text { the last } 12 \text { months }\end{array}$ & 0.084 & 0.034 & 0.050 & $* *$ \\
\hline $\begin{array}{l}\text { Number of technological innovations adopted by farmers in the } \\
\text { last } 12 \text { months }\end{array}$ & 0.366 & 0.104 & 0.262 & $* * *$ \\
\hline Number of technological innovations applied now & 0.284 & 0.070 & 0.214 & $* * *$ \\
\hline $\begin{array}{c}\text { Frequency in discussing the problem of farming production } \\
\text { with other actors in the group }\end{array}$ & 0.089 & 0.015 & 0.074 & $* * *$ \\
\hline Knowledge sharing capability & 0.029 & 0.005 & 0.024 & $*$ \\
\hline $\begin{array}{c}\text { Number of farmers given new information or methods by } \\
\text { respondent farmers }\end{array}$ & 0.029 & 0.005 & 0.024 & $*$ \\
\hline Knowledge transfer capability & 0.423 & 0.274 & 0.149 & $* * *$ \\
\hline $\begin{array}{c}\text { The number of ideas that farmers learn from other farmers and } \\
\text { other actors }\end{array}$ & 0.423 & 0.274 & 0.149 & $* * *$ \\
\hline Functioning feedback mechanism & 0.127 & 0.031 & 0.096 & $* * *$ \\
\hline $\begin{array}{l}\text { Frequency of interaction with officers related to business } \\
\text { production in groups. }\end{array}$ & 0.127 & 0.031 & 0.096 & $* * *$ \\
\hline
\end{tabular}

at-test for mean differences of the two groups. ${ }^{* * *}$ Significant at level $1 \%$. ${ }^{* *}$ Significant at level $5 \%$.

*Significant at level $10 \%$

The measurement of the resilience indicator values of organic and conventional vegetable farmers' livelihoods are presented in Figure 2. The value of buffer capacity of organic vegetable farmers $(0.321)$ is higher than conventional vegetable farmers (0.283), learning capacity of organic farmers (0.229) is higher than conventional vegetable farmers (0.156), and the value of organic farmers' self-organization (0.559) is higher than conventional farmers (0.524). Organic farmers have a better buffer capacity, learning capacity and self-organization in dealing with climate change than conventional vegetable farmers. Self-organizing ability of organic vegetable farmers is slightly different from conventional vegetable farmers, indicating that organic and conventional vegetable farmers are in the trustworthy community and relatively close distance in obtaining the inputs. 


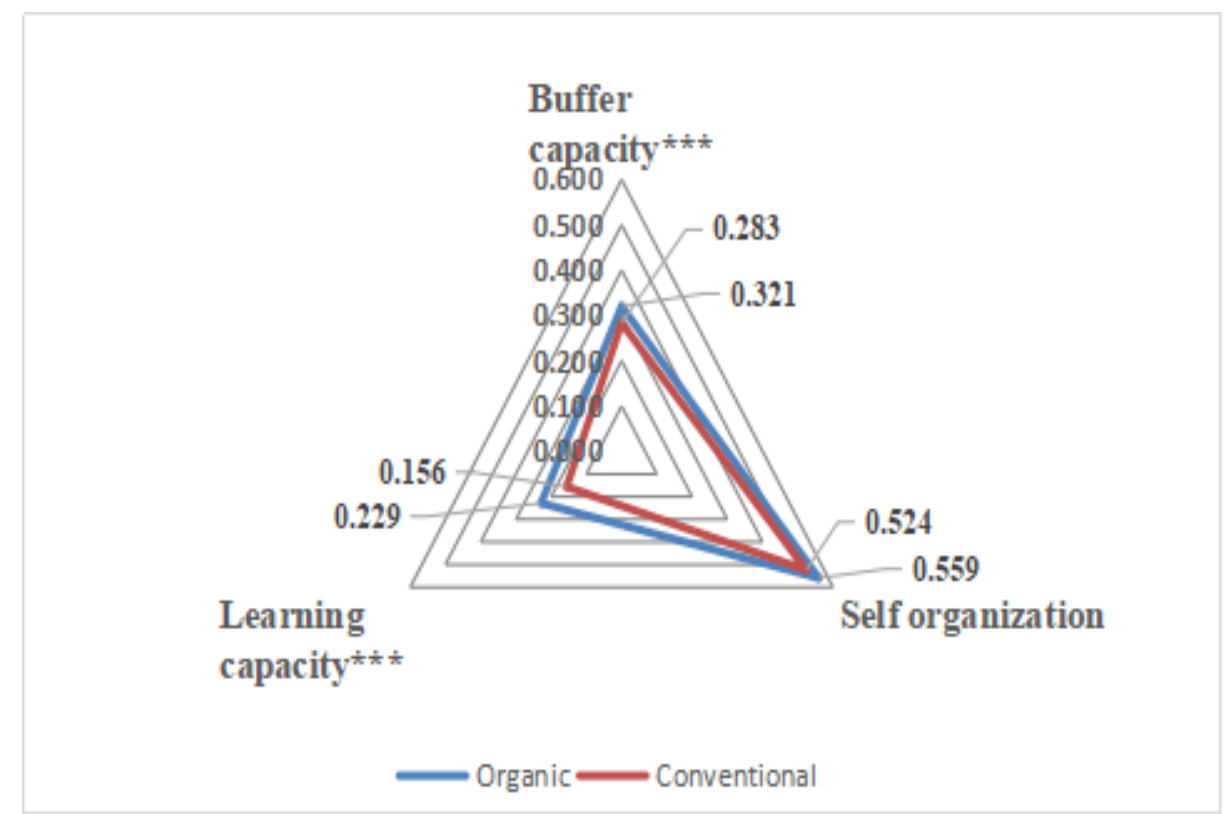

Figure 2. Comparison between the indicator value of livelihood resilience between organic vegetable farmers and conventional vegetable farmers. (Note: the highest value of each indicator is $1 ; * * *$ significant at the level of $1 \%$ based on the results of the $t$-test for mean differences of the two groups)

\section{Livelihood resilience index of organic and conventional farmers in dealing with climate change}

Figure 3 showed that the value of livelihood resilience of organic vegetable farmers (0.375) in dealing with climate change was higher than that of conventional vegetable farmers (0.329). Organic vegetable farmers are more resilient to climate change than conventional vegetable farmers. Figure 2 shows that the self-organization of organic vegetable farmer and conventional vegetable farmers contribute the most to livelihood resilience index. The second and third indicator that contributes to livelihood resilience index is buffer capacity and learning capacity.

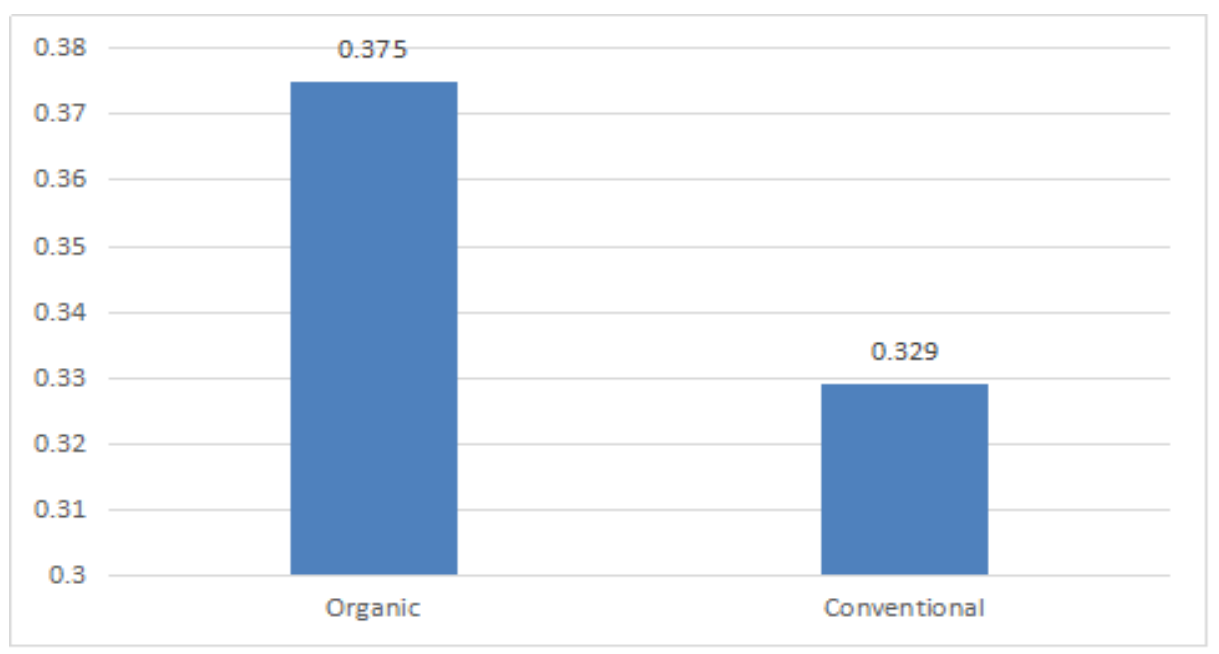

Figure 3. Livelihood resilience index of organic and conventional vegetable farmers 


\section{Determinants that influence the livelihood resilience of organic and conventional vegetable farmers in dealing with climate change}

Important determinants that affect the livelihood resilience index of organic and conventional vegetable farmers in dealing with climate change are presented in Table 8. The analysis shows that the livelihood resilience index of organic vegetable farmers in dealing with climate change is influenced by household size, engagement in trade, access to extension service and the number of adaptation strategies adopted by farmers to reduce the impact of climate change. On the other hand, conventional farmers' livelihood resilience index in dealing with climate change is influenced by household size, farmers' access to climate information, access to climate training and the number of strategies adopted by conventional vegetable farmers to reduce the negative impacts of climate change. Each important determinant that influences the level of livelihood resilience of organic and conventional farmers in dealing with climate change are listed as follows:

1. Age

The age of farmers does not affect livelihood resilience index of both organic and conventional farmers in the face of climate change.

2. Household size

Household size affects the level of livelihood resilience of organic and conventional farmers. The negative household size coefficient indicates that the increase in household size of organic and conventional farmers will reduce the level of livelihood resilience of farmers in dealing with climate change. The coefficient of household size for organic and conventional farmers is 0.012 and 0.008 respectively, indicating that any increase in household size of one person will reduce the livelihood resilience index of organic farmers by 0.012 points and conventional farmers by 0.008 points.

3. Engagement in trade

Engagement in trade has a significant effect on the livelihood resilience index of organic farmers. Positive coefficients indicate that farmers who have established trading cooperation in selling farm products with other parties will have higher resilience in dealing with climate change than farmers who do not cooperate with other parties.

4. Access to credit

The access of organic and conventional farmers to credit does not affect the livelihood resilience index of farmers in the face of climate change.

5. Access to extension services

Farmer's access to extension services only has a significant effect on the livelihood resilience of organic farmers in the face of climate change. The coefficient of access to extension services with a positive sign indicates that organic farmers who have access to extension services have a better livelihood resilience in facing climate change than farmers who do not have access to extension services.

6. Access to climate information

Farmer's access to climate information influences the livelihood resilience indexes of conventional farmers in the face of climate change. The access to climate information coefficient of organic farmers having a positive sign indicates that organic farmers who have access to climate information have better livelihood resilience in dealing with climate change than farmers who do not have access to climate information.

7. Access to climate training

Farmers' access to climate training has a positive and significant effect on conventional farmers' livelihood resilience index, meaning that conventional farmers 
who have access to climate training have higher resilience in dealing with climate change than farmers who do not have access to climate training.

8. Number of adaptation strategies

The number of adaptation strategies will affect the level of livelihood resilience of organic and conventional farmers in the face of climate change. The number of adaptation strategies coefficient shows a positive sign, meaning that each increase in the number of adaptation strategies implemented by organic and conventional farmers can increase the livelihoods resilience index of farmers in dealing with climate change.

Table 8. Analysis of OLS important determinants that influence the level of livelihood resilience of organic and conventional farmers in dealing with climate change

\begin{tabular}{|c|c|c|c|c|c|}
\hline \multirow{2}{*}{$\frac{\text { Explanatory variabel }}{\text { Age }}$} & \multirow{2}{*}{$\begin{array}{c}\text { Expected sign } \\
+\end{array}$} & \multicolumn{2}{|c|}{ Organic farmers } & \multicolumn{2}{|c|}{$\begin{array}{c}\text { Conventional } \\
\text { farmers }\end{array}$} \\
\hline & & $\begin{array}{c}0.000 \\
(0.001)\end{array}$ & & $\begin{array}{l}-0.001 \\
(0.001)\end{array}$ & \\
\hline Household size & + & $\begin{array}{l}-0.012 \\
(0.005) \\
\end{array}$ & $* *$ & $\begin{array}{l}-0.008 \\
(0.005) \\
\end{array}$ & $*$ \\
\hline Engagement in trade & + & $\begin{array}{c}0.033 \\
(0.018)\end{array}$ & * & $\begin{array}{c}0.007 \\
(0.015)\end{array}$ & \\
\hline Access to credit & + & $\begin{array}{l}-0.005 \\
(0.014) \\
\end{array}$ & & $\begin{array}{l}-0.022 \\
(0.016) \\
\end{array}$ & \\
\hline Access to extension services & + & $\begin{array}{c}0.023 \\
(0.013)\end{array}$ & $*$ & $-0.010(0.008)$ & \\
\hline Access to climate information & + & $\begin{array}{c}0.002 \\
(0.013) \\
\end{array}$ & & $\begin{array}{c}0.027 \\
(0.012) \\
\end{array}$ & \\
\hline Access to climate training & + & $\begin{array}{c}0.030 \\
(0.021)\end{array}$ & & $\begin{array}{c}0.060 \\
(0.021)\end{array}$ & $* *$ \\
\hline Number of adaptation strategies & + & $\begin{array}{c}0.015 \\
(0.005) \\
\end{array}$ & $* *$ & $\begin{array}{c}0.011 \\
(0.004) \\
\end{array}$ & $* *$ \\
\hline Constant & + & $\begin{array}{c}0.289 \\
(0.048)\end{array}$ & $* * *$ & $\begin{array}{c}0.313 \\
(0.041)\end{array}$ & $* * *$ \\
\hline Sig. F test & & 0.007 & & 0.005 & \\
\hline R-Square & & 0.179 & & 0.126 & \\
\hline
\end{tabular}

The exploratory OLS model has passed all the diagnostic tests, such as multicollinearity tests, heteroscedasticity test, and diagnostic plots to check the normality and linearity assumptions. ${ }^{* * * *}$ Significant at level $1 \%$. ${ }^{* *}$ Significant at level 5\%. ${ }^{*}$ Significant at level $10 \%$. The standard error in parentheses

\section{Discussion}

The study confirms that the buffer capacity, self-organization and learning capacity of organic vegetable farmers is higher than that of conventional vegetable farmers. Social capital, natural capital and physical that make up the buffer capacity of organic vegetable farmers is higher than that of conventional vegetable farmers. Organic vegetable farmers also have more fertile land and equipment to support farming activities. However, financial capital of organic vegetable farmers in the study area is lower than that of conventional farmers, although vegetable farming income received by organic farmers is higher than that received by conventional farmers. Farming income 
and participation of farmers in groups can increase buffer capacity in dealing with climate change (Jacobi et al., 2015).

Organic vegetable farmers have better self-organization and learning capacity than conventional farmers. The majority of organic vegetable farmers in research locations are incorporated in farmer groups. Farmer groups can also increase learning capacity of organic vegetable farmers to be higher than that of conventional vegetable farmers. Farmers can exchange information related to cultivation, plant disease, pests, harvests, product prices and farming problems due to climate change. Farmer groups also become a key place for farmers to obtain and exchange information and technology between farmers (Bryan et al., 2013). It is noteworthy that organic vegetable farmers and their surrounding communities trust each other very well. Organic farmers can also get their farming inputs in a relatively closer distance than that of conventional farmers. For example, organic farmers can easily find the ingredients for making vegetable pesticides in their surroundings. Organic vegetable farmers receive various information from farmer groups and surrounding communities. The results of this study are in line with those of Jacobi et al. (2015), which states that organic farmers have better networks than conventional farmers.

The second analysis confirms that organic vegetable farmers in the study area are more resilient than conventional vegetable farmers, which is in line with Jacobi et al. (2015). Organic farmers are more resilient because of group membership or cooperation that can increase their adaptive capacity and buffer capacity (Jacobi et al., 2015). Resilience of organic and conventional vegetable farmers in research locations rests on self-organizations. Vegetable farmers in the face of climate change should use this selforganization ability to increase buffer capacity and learning capacity. In many developing countries, organic farming systems have the potential to maintain farmers' livelihoods when farmers are adversely affected by climate change. In addition, organic farming production and income are often the same or higher than those of conventional farmers (Scialabba, 2007). Resilience of organic farming also depends on the ability and experience of farmers in adaptation (Milestad and Darnhofer, 2003).

The third analysis confirms the important determinants that influence the level of resilience of organic and conventional vegetable farmers in the face of climate change. Important determinants affecting the livelihood resilience index of organic farmers in dealing with climate change are household size, engagement in trade, access to extension services, and the number of adaptation strategies implemented by farmers. On the contrary, conventional farmers' livelihood resilience index in dealing with climate change is affected by household size, access to climate information, access to climate training, and the number of adaptation strategies applied by conventional farmers to reduce the impact of climate change.

The household size of vegetable farmers in the study location will influence the livelihood resilience index of organic vegetable farmers and conventional vegetable farmers in the face of climate change. However, this result is not in line with the research conducted by Weldegebriel and Amphune (2017), indicating that household size does not affect the livelihood resilience of farmers in the research area. The household size of organic vegetable farmers and conventional vegetable farmers in the research location indicate the number of family members to be borne by the household. Therefore, an increase of household size would reduce the livelihood resilience of farmers in dealing with climate change. Engagement in trade is positively and significantly affected by the resilience of organic vegetable farmers in the face of 
climate change. The positive relationship between engagement in trade with farmers' resilience in dealing with climate change supports the research of Jacobi et al. (2015). Most of organic vegetable farmers in the research locations have marketing network for agricultural products with other parties. This marketing network ensures certain sales and price, making organic vegetable farmers have a higher income than conventional vegetable farmers. The received income of vegetable farming can increase the buffer capacity of farmers in dealing with climate change.

Organic vegetable farmers in the study area have better access to credit and extension services. Good accessibility can improve the self-organization and learning capacity of farmers in facing climate change. On this account, Jacobi et al. (2015) state that organic farmers are more resilient because they are integrated with farmer organizations that can increase their adaptive capacity and buffer the capacity to deal with climate change. Vegetable farmers at the research location regularly hold farmer group meetings, such as every once a month. At this group meeting, farmers obtain and share information about technology to increase production and efforts made to deal with the negative impacts of climate change. Other factors that influence the livelihood resilience of farmers in dealing with climate change are farmers' access to climate-related information and climate training. The results showed that conventional vegetable farmers' access to climate information and climate training had a positive effect on livelihood resilience, meaning that farmers who had access to climate information and climate training would be more resilient than those without access.

The number of adaptation strategies applied by farmers to reduce the negative impact of climate change also has a positive effect on the level of livelihood resilience of farmers in the face of climate change. In other words, an increase in each number of adaptation strategy can increase the livelihood resilience of farmers in the face of climate change. Adaptation of farmers to climate change will help farmers reduce the adverse effects of climate change. Vegetable farmers at the research site adopted an adaptation strategy in the form of mixed cropping, using superior varieties, planting water-intensive plants, rotating crops, adjusting planting and harvesting times, increasing doses of organic matter, using mulch, using shade, changing irrigation techniques, and using prey institutions. The number of adaptation strategies implemented by farmers to reduce the impact of climate change ranges from one to nine strategies. The combination of adaptation strategies implemented by farmers aims to maintain farming production. Production continuity can increase farmers' income so that the buffer capacity of farmers in facing climate change increases. This result is in line with the research conducted by (Tambo and Wünscher, 2017; Uy et al., 2011) Improved adaptation strategies are required to reduce the negative impacts of climate change, and the government plays a key role in increasing farmers' awareness and knowledge of climate change (Korkmsz, 2018). Farmers should consider the current and future impacts of climate change to establish adaptation strategies to be implemented in the face of climate change (Nhuan et al., 2018).

\section{Conclusions}

Overall, organic vegetable farmers have a better buffer capacity, self-organization, and learning capacity than conventional vegetable farmers. These three components contribute to the higher level of livelihood resilience index, so organic vegetable farmers are more resilient in dealing with climate change than conventional vegetable 
farmers. Self-organization contributes the most to improving livelihood resilience, which increases the livelihood resilience index of farmers in the face of climate change. Therefore, both organic and conventional vegetable farmers should have applied selforganization to increase learning capacity and buffer capacity. It is possible to improve the resilience level of organic vegetable farmers in dealing with climate change through engagement in trade, accessibility of organic vegetable farmers to extension services, and more number of adaptation strategies. Meanwhile, the resilience level of conventional vegetable farmers can be increased through access to climate information, climate training access, and number of farmers' adaptation strategies. This study recommends that policymakers need to develop organic farming and institutions through cooperation and climate training program to increase farmers' resilience in dealing with climate change.

Acknowledgements. We also would like to express our sincere gratitude to Indonesian Agency for Agricultural Research and Development Ministry of Agriculture. This paper is part of a Ph.D. research project at Univeristas Gadjah Mada, Yogyakarta, Indonesia. Our sincere appreciation is also extended to all parties who have provided information to complete this article.

\section{REFERENCES}

[1] Abid, M., Schneider, U. A., Scheffran, J. (2016): Adaptation to climate change and its impacts on food productivity and crop income: perspectives of farmers in rural Pakistan. - Journal Rural Studies 47: 254-266. https://doi.org/10.1016/j.jrurstud.2016.08.005.

[2] Adiyoga, W., Lukman, L. (2018): Vegetable farmers' perception on adaptation to climate change in lowland and highland areas of South Sulawesi (Persepsi dan adaptasi petani sayuran terhadap perubahan iklim di Sulawesi Selatan). - Jurnal Hortikultura 27: 279296. https://doi.org/10.21082/jhort.v27n2.2017.p279-296.

[3] Ali, A., Erenstein, O. (2017): Assessing farmer use of climate change adaptation practices and impacts on food security and poverty in Pakistan. - Climate Risk Management 16: 183-194. https://doi.org/10.1016/j.crm.2016.12.001.

[4] Ayyogari, K., Sidhya, P., Pandit, M. K. (2014): Impact of climate change on vegetable cultivation: A Review. - International Journal of Agriculture, Environment and Biotechnology 7: 145-155. https://doi.org/10.5958/j.2230-732X.7.1.020.

[5] Bryan, E., Ringler, C., Okoba, B., Roncoli, C., Silvestri, S., Herrero, M. (2013): Adapting agriculture to climate change in Kenya: household strategies and determinants. - Journal of Environmental Management 114: 26-35. https://doi.org/10.1016/j.jenvman.2012.10.036.

[6] Deressa, T. T., Hasan, R. M., Ringler, C., Alemu, T. T., Yusuf, M., Tadesse, T., Hassan, R. M., Ringler, C., Alemu, T. T., Yesuf, M., Deressa, T. T., Hassan, R. M., Ringler, C., Alemu, T. T., Yesuf, M. (2009): Determinants of farmers' choice of adaptation methods to climate change in the Nile Basin of Ethiopia. - Global Environmental Change 19: 248255. https://doi.org/10.1016/j.gloenvcha.2009.01.002.

[7] FAO (2016): Resilience Index Measurement and Analysis Model. - Food and Agriculture Organization of the United Nations, Rome.

[8] Fosu-Mensah, B. Y., Vlek, P. L. G., MacCarthy, D. S. (2012): Farmers' perception and adaptation to climate change: A case study of Sekyedumase district in Ghana. Environment, Development and Sustainability 14: 495-505. https://doi.org/10.1007/s10668-012-9339-7. 
[9] Gbetibouo, G. A., Ringler, C., Hassan, R. (2010): Vulnerability of the South African farming sector to climate change and variability: an indicator approach. - Natural Resources Forum 34: 175-187. https://doi.org/10.1111/j.1477-8947.2010.01302.x.

[10] Haryono, Las, I. (2011): Mitigation strategy and agricultural adaptation to global climate change impacts (Strategi mitigasi dan adaptasi pertanian terhadap dampak perubahan iklim global), in: Prosiding Seminar Nasional "Era Baru Pembangunan Pertanian: Strategi Mengatasi Masalah Pangan, Bioenergi dan Perubahan Iklim. - Pusat Sosial EKonomi Kementerian Pertanian, Bogor, pp. 1-10.

[11] Ichdayanti, L. I. (2014): Farmer's responses and adaptation to climate change (Respon petani dan adaptasinya terhadap perubahan iklim). - Jurnal Agribisnis 8: 155-170.

[12] Irham, Saito, O., Mohri, H., Wirakusuma, G., Rohmah, F., Perwitasari, H. (2018): Traditional Farmers' Adaptation Strategies on Climate Change of Different Environmental Conditions in Yogyakarta Province, Indonesia. - In: Takeuchi, K., Saito, O., Matsuda, H., Mohan, G. (eds.) Resilient Asia: Fusion of Traditional and Modern Systems for a Sustainable Future. Springer Imprint, Tokyo.

[13] Jacobi, J., Schneider, M., Mariscal, M. P., Huber, S., Weidmann, S., Bottazzi, P., Rist, S. (2015): Farm resilience in organic and nonorganic cocoa farming systems in Alto Beni, Bolivia. - Agroecology and Sustainable Food Systems 39: 798-823. https://doi.org/10.1080/21683565.2015.1039158.

[14] Keil, A., Zeller, M., Wida, A., Sanim, B., Birner, R. (2008): What determines farmers' resilience towards ENSO-related drought? An empirical assessment in Central Sulawesi, Indonesia. - Climate Change 86: 291-307. https://doi.org/10.1007/s10584-007-9326-4.

[15] Korkmsz, M. (2018): Public awareness and perception of climate change: differences in concern about climate change in the west Mediterranean region of Turkey. - Applied Ecology and Environmental Research 16: 4039-4050. https://doi.org///dx.doi.org/10.15666/aeer/1604_40394050.

[16] Kurniawati, F. (2012): Knowledge and adaptation of vegetable farmers to climate change (Pengetahuan dan adaptasi petani sayuran terhadap perubahan iklim. Studi kasus: Desa Cibodas, Kecamatan Lembang, Kabupaten Bandung Barat). - Thesis. Universitas Padjajaran, Bandung.

[17] Lal, S. S. (2014): Climate change resilience and vulnerability of farmers in Nepal. Doctoral Dissertation. Hiroshima University, Jepang.

[18] Makate, C., Makate, M., Mango, N. (2017): Smallholder farmers' perceptions on climate change and the use of sustainable agricultural practices in the Chinyanja Triangle, Southern Africa. - Social Science 6: 1-14. https://doi.org/10.3390/socsci6010030.

[19] Marseva, A. D., Putri, E. I. K., Ismail, A. (2016): Analysis of resilience factors of farmer households in facing climate variability (Analisis faktor resiliensi rumah tangga petani dalam menghadap variabilitas iklim). - Jurnal Ekonomi dan Pembangunan Indonesia 17: $15-27$.

[20] Milambo, K. H. (2013): Farmers' adaptations to rainfall related climate variability risks and their implications on food security in the semi-arid Sikonge District, Tanzania. Thesis. Sokoine University, Marogoro.

[21] Milestad, R., Darnhofer, I. (2003): Building farm resilience : the prospects and challenges of organic farming. - Journal of Sustainable Agriculture 23: 81-97. https://doi.org/10.1300/J064v22n03_09.

[22] Murphy, A. (2015): Creating Resilient Livelihoods A Cross-sectional Study of Livestock Farmers in the Paraguayan Chaco. - Wageningen University, Netherlands.

[23] Nhuan, M. T., Tue, N. T., Quy, T. D. (2018): Enhancing Resilience to Climate Change and Disasters for Sustainable Development: Case Study of Vietnam Coastal Urban Areas. - In: Takeuchi, K., Saito, O., Matsuda, H., Mohan, G. (eds.) Resilient Asia: Fusion of Traditional and Modern Systems for a Sustainable Future. Springer Imprint, Tokyo.

[24] Rejekiningrum, P., Las, I., Amien, I., Surmaini, E., Pramudia, A., Sarvina, Y. (2011): Adaptation to climate change in the agricultural sector (Adaptasi perubahan iklim sektor 
pertanian). - Badan Penelitian dan Pengembangan Kementerian Pertanian Indonesia, Jakarta.

[25] Ruminta (2015): Analysis of decreased rice production due to climate change in Bandung Regency, West Java (Analisis penurunan produksi tanaman padi akibat perubahan iklim di Kabupaten Bandung Jawa Barat). - Jurnal Kultivasi 15: 37-45.

[26] Scialabba, N. (2007): Organic agriculture and food security. - Conference on Organic Agriculture and Food Security, Rome, 3-5 May.

[27] Speranza, I. C., Wiesmann, U., Rist, S. (2014): An indicator framework for assessing livelihood resilience in the context of social-ecological dynamics. - Global Environmental Change 28: 109-119. https://doi.org/10.1016/j.gloenvcha.2014.06.005.

[28] Surmaini, E., Runtunuwu, E., Irsal, L (2011): Efforts of agricultural sector in dealing with climate change (Upaya sektor pertanian dalam menghadapi perubahan iklim). - Jurnal Litbang Pertanian 30: 1-7. https://doi.org/10.21082/JP3.V30N1.2011.P1-7.

[29] Tambo, J. A (2016): Adaptation and resilience to climate change and variability in northeast Ghana. - International Journal of Disaster Risk Reduction 17: 85-94. http://dx.doi.org/10.1016/j.ijdrr.2016.04.005.

[30] Tambo, J. A., Wünscher, T. (2017): Enhancing resilience to climate shocks through farmer innovation: evidence from northern Ghana. - Regional Environmental Change 17: 1505-1514. https://doi.org/10.1007/s10113-017-1113-9.

[31] Tanner, T., Lewis, D., Wrathall, D., Bronen, R., Cradock-Henry, N., Huq, S., Lawless, C., Nawrotzki, R., Prasad, V., Rahman, M. A., Alaniz, R., King, K., McNamara, K., Nadiruzzaman, M., Henly-Shepard, S., Thomalla, F. (2015): Livelihood resilience in the face of climate change. - Nature Climate Change 1: 1-4. https://doi.org/10.1038/nclimate2431.

[32] Tesso, G., Emana, B., Ketema, M. (2012): Analysis of vulnerability and resilience to climate change induced shocks in North Shewa, Ethiopia. - Agricultural Sciences 03: 871-888. https://doi.org/10.4236/as.2012.36106.

[33] Thulstrup, A. W. (2015): Livelihood resilience and adaptive capacity: tracing changes in household access to capital in Central Vietnam. - World Development 74: 352-362. https://doi.org/10.1016/j.worlddev.2015.05.019.

[34] UNDP (2006): Human Development Report 2006: Beyond Scarcity: Power, Poverty and the Global Water Crisis. - UNDP, New York.

[35] Uy, N., Takeuchi, Y., Shaw, R. (2011): Local adaptation for livelihood resilience in Albay, Philippines. $\quad-\quad$ Environmental Hazards 10: 139-153. https://doi.org/10.1080/17477891.2011.579338.

[36] Wahyuni, K. I. (2016): Economic value and livelihood vulnerability index of farmer's household in District Timor Tengah Utara, Province East Nusa Tenggara (Penilaian ekonomi dan indeks kerentanan rumahtangga petani di Kabupaten Timor Tengah Utara, Provinsi Nusa Tenggara Timur ). - Thesis. Institut Pertanian Bogor, Bogor.

[37] Weldegebriel, Z. B., Amphune, B. E. (2017): Livelihood resilience in the face of recurring floods : an empirical evidence from Northwest Ethiopia. - Geoenvironmental Disasters 4: 1-19. https://doi.org/10.1186/s40677-017-0074-0. 


\section{APPENDIX}

\section{SURVEY QUESTIONNAIRE}

\section{LIVELIHOOD RESILIENCE OF VEGETABLE FARMERS: EFFICACY OF ORGANIC FARMING IN DEALING WITH CLIMATE CHANGE IN JAVA, INDONESIA}

This research survey questionnaire is purely for academic purposes with the objective "Assessing and comparing livelihood resilience between organic and conventional farmers and it determinant". You are assured of confidentiality of any view expressed in relation to this research. I therefore entreat you to provide information as accurate as possible for true results. Thank you for your kind cooperation.

\begin{tabular}{|ll|}
\hline Questionnaire number & $:$ \\
\hline Name of interviewer & $:$ \\
\hline Date of interviewer & $:$ \\
\hline Name of respondent & $:$ \\
\hline District & $:$ \\
\hline Organic/conventional & $:$ \\
\hline
\end{tabular}

\section{A. FARMERS' CHARACTERISTICS AND ACCESSIBILITY}

1. Age years

2. Household size person/people

\begin{tabular}{|c|c|}
\hline Status in family & Age (years) \\
\hline & \\
\hline & \\
\hline & \\
\hline
\end{tabular}

3. Do you have access to cooperation in selling crops? $\square$ Yes, $\square$ No

4. Do you have access to credit institution? $\square$ Yes, $\square$ No

5. Do you have access to extension services? $\square$ Yes, $\square$ No

6. Do you have access to climate information? $\square$ Yes, $\square$ No

7. Do you have access to participate in climate training? $\square$ Yes, $\square$ No

\section{B. ADAPTATION TO CLIMATE CHANGE}

1. Have you made any adjustments in your farming ways in response to climate change ? $\square$ Yes, No

2. What adjustments in your farming ways have you made in response to climate change?

\begin{tabular}{|l|l|}
\hline \multicolumn{1}{|c|}{ Adjustment in farming } & Yes/No \\
\hline Implementing mixed cropping & \\
\hline Using superior varieties & \\
\hline Growing non water-intensive vegetable & \\
\hline Implementing crop rotation & \\
\hline Adjusting planting and harvesting dates & \\
\hline Increasing the does of organic matter & \\
\hline
\end{tabular}




\begin{tabular}{|l|l|}
\hline Using mulch & \\
\hline Using shade & \\
\hline Changing irrigation techniques & \\
\hline Using pranata mangsa & \\
\hline
\end{tabular}

\section{LIVELIHOOD RESILIENCE}

1. BUFFER CAPACITY

a) Human Capital

1. Education : :................. years

2. Farming experience $\quad:$................. years

3. Do you have other ability beside farming? $\square$ Yes, (specify)................................................, $\square$ No

4. How many family members are permanently ill? .......... person/people

\section{b) Financial Capital}

1. Please specify the type, quantity and selling price of the vegetable products that you have produced for the past year.

\begin{tabular}{|l|l|l|}
\hline Type & Quantity & Price (USD/kg) \\
\hline & & \\
\hline & & \\
\hline & & \\
\hline
\end{tabular}

2. Please specify the type, number of livestock and the price of livestock that you currently have.

\begin{tabular}{|c|c|c|}
\hline $\begin{array}{c}\text { Type } \\
\text { (cow/goat/others) }\end{array}$ & Quantity & $\begin{array}{c}\text { Price per unit } \\
\text { (USD) }\end{array}$ \\
\hline & & \\
\hline & & \\
\hline & & \\
\hline
\end{tabular}

3. Please state your work, time and income for you and your family members obtained from work as a laborer in the past year.

\begin{tabular}{|c|c|c|c|c|c|}
\hline $\begin{array}{c}\text { Actor } \\
\text { (farmer/wife/ } \\
\text { others) }\end{array}$ & Job & $\begin{array}{c}\text { Working } \\
\text { days a } \\
\text { month }\end{array}$ & $\begin{array}{c}\text { Daily } \\
\text { earnings }\end{array}$ & $\begin{array}{c}\text { Revenue } \\
\text { per month }\end{array}$ & $\begin{array}{c}\text { Period of work } \\
\text { per year }\end{array}$ \\
\hline & & & & & \\
\hline & & & & & \\
\hline & & & & & \\
\hline
\end{tabular}

c) Social Capital

1. Asset increase due to organization partnership

Please specify the name of group and the income you earn from your participation in a group.

\begin{tabular}{|c|c|}
\hline Name of group & Income (USD) \\
\hline & \\
\hline & \\
\hline
\end{tabular}

2. Support of workforce from the group

Please state the group name, number of work days and the amount of labor support that you have received from group members in vegetable farming activities during the past year.

\begin{tabular}{|c|c|c|c|}
\hline Name of group & Farming activities & Number of work days & Amount of labor support \\
\hline & & & \\
\hline
\end{tabular}




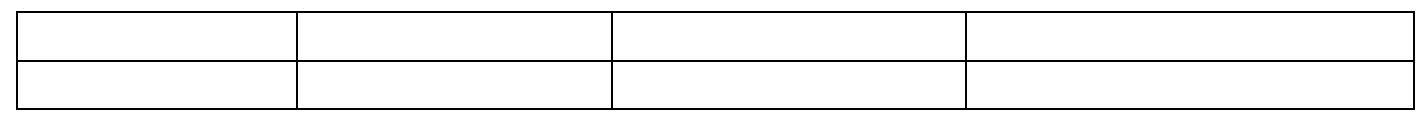

3. Use of group equipment

Please specify the type and number of group equipment you have used in the past year.

\begin{tabular}{|c|c|c|}
\hline Name of group & Equitment & Quantity \\
\hline & & \\
\hline & & \\
\hline & & \\
\hline
\end{tabular}

d) Physical Capital

Do the assets that you currently have, such as machinery, buildings, equipment, water storage, remain productive?

\begin{tabular}{|l|l|l|}
\hline \multicolumn{1}{|c|}{ Assets } & Quantity & Price per unit (USD) \\
\hline $1 . \quad$ Machinery & & \\
\hline 2. Water storage & & \\
\hline 3. & & \\
\hline 4. & & \\
\hline
\end{tabular}

e) Natural Capital

In your opinion, what is the level of soil fertility on your vegetable farming land? Please fill in 1 if the land is very infertile, 2 if it is not fertile, 3 if it is fertile, 4 if fertile, and 5 if it is very fertile.

\begin{tabular}{|c|c|c|}
\hline Plot & Land area $\left(\mathrm{m}^{2}\right)$ & Soil fetility \\
\hline 1 & & \\
\hline 2 & & \\
\hline
\end{tabular}

\section{SELF-ORGANIZATION}

\section{a) Cooperation and network}

Please specify the name of the group or association that you are following.

\section{b) Trust}

What is the level of trust of the people around you in lending and borrowing? ..... \%

\begin{tabular}{|l|c|}
\hline \multicolumn{1}{|c|}{ Questions } & $\begin{array}{c}\text { Number } \\
\text { of } \\
\text { People }\end{array}$ \\
\hline $\begin{array}{l}\text { For example, there are five people around you who need funds for farming, and } \\
\text { request a loan without interest. How many people will you give a loan? }\end{array}$ \\
\hline $\begin{array}{l}\text { For example, you need a loan for farming. If there are five people around you, how } \\
\text { many people will give you a loan? }\end{array}$ & \\
\hline
\end{tabular}

\section{c) Reliance on own resources}

What is the closest distance between farming land and input resources? ........ meters.

\section{LEARNING CAPACITY}

\section{a) Knowledge of treat and opportunities}

Could you mention the characteristics of the vegetables infected with the primary disease pests such as the following:

\begin{tabular}{|ll|c|}
\hline \multicolumn{1}{|c|}{ Primary disease pests } & Yes/No \\
\hline 1. & Shrinking leaves, dry shoots curved due to aphids. & \\
\hline 2. & The leaves are seen shiny white spots and the become brown which shows & \\
\hline
\end{tabular}




\begin{tabular}{|rl|l|}
\hline trips. & \\
\hline 3. & $\begin{array}{l}\text { The leaves are damaged, hollow and the remaining leaf bones are attacked by } \\
\text { caterpillars. }\end{array}$ & \\
\hline 4. & $\begin{array}{l}\text { For vegetables that have fruit, there are black streaks on the fruit and rot, } \\
\text { which indicates fruit flies. }\end{array}$ & \\
\hline 5. & $\begin{array}{l}\text { Wilt that occurs in all parts of the plant starting from the leaves and suddenly } \\
\text { shows attacked by bacterial wilt. }\end{array}$ & \\
\hline 6. & $\begin{array}{l}\text { Rounded spots resembling frog eyes with brownish edges on leaves that } \\
\text { show leaf spots. }\end{array}$ & \\
\hline 7. & The fruit is brown and black spotted that indicate an anthracnose attack. & \\
\hline 8. & The fruit is brown, rotten, and wet due to fruit rot. & \\
\hline
\end{tabular}

Do you know the technology below to increase your vegetable farming production? Please give a $\operatorname{sign}(\mathrm{V})$ if you know.

\begin{tabular}{|c|c|}
\hline Technology & $\operatorname{Sign}(\mathrm{V})$ \\
\hline $\begin{array}{l}\text { 1. Use of superior seeds without genetic engineering (organic), and superior } \\
\text { commercial seeds (conventional). }\end{array}$ & \\
\hline $\begin{array}{l}\text { 2. Seedling and sorting of seeds before moving to the field, especially for } \\
\text { small fruiting plants such as mustard greens, tomatoes, and eggplants. } \\
\text { Whereas, for large fruiting plants such as cucumber, long beans, and beans, } \\
\text { can be planted directly. }\end{array}$ & \\
\hline Use of mulch for plants such as tomatoes, eggplants, and beans. & \\
\hline Use of roofed shade. & \\
\hline Making beds with a width of $100-120 \mathrm{~cm}$ and a height of $30 \mathrm{~cm}$. & \\
\hline 6. The land is cultivated by hoeed or plowed to a depth of $30-40 \mathrm{~cm}$. & \\
\hline $\begin{array}{l}\text { 7. The provision of manure is } 2-3 \text { tons per } 1000 \text { square meters for organic } \\
\text { farming, and around } 1.5-3 \text { tons per hectare for conventional farming. }\end{array}$ & \\
\hline 8. $\quad$ Recommended plant spacing according to each type of vegetable crop. & \\
\hline $\begin{array}{l}\text { 9. Supplementary fertilization according to recommendation, namely the } \\
\text { provision of manure, urine or other organic material (organic), and fertilizer } \\
\text { application according to recommendations per plant. }\end{array}$ & \\
\hline 10. Crop rotation. & \\
\hline 11. Irrigation and watering management. & \\
\hline $\begin{array}{l}\text { 12. Mechanical and organic pest and disease control (organic farming), and } \\
\text { according to the principle of Integrated Pest Mangement (conventional } \\
\text { farming). }\end{array}$ & \\
\hline 13. Yields are placed in shaded places and treated with care. & \\
\hline
\end{tabular}

\section{b) Shared vision and commitment to learning}

1. How many regular meetings with extension agents in the previous year?......

2. Did you allocate time to find information on technology? $\square$ Yes, that is ... minutes/month. $\square$ No.

3. How many times have you discussed the development and performance of farming with farmers, extension, or other stakeholders during the last 12 months?

\begin{tabular}{|l|c|c|}
\hline \multicolumn{1}{|c|}{ Actor } & $\begin{array}{c}\text { Frequency of farming } \\
\text { development discussion }\end{array}$ & $\begin{array}{c}\text { Frequency of farming } \\
\text { performance discussion }\end{array}$ \\
\hline Farmer & & \\
\hline Extension officer & & \\
\hline District agricultural officer & & \\
\hline Researcher & & \\
\hline Other (specify) & & \\
\hline
\end{tabular}

\section{c) Knowledge identification capability-monitoring}

1. In your opinion, when is the right time to sell your agricultural products for the last 12 months to get a good price?.

2. How many times have you consulted about farming planning forecasting? 
3. Among the following technologies, give a sign (V) if the technology is used now and in the future, and technology has been tried once and adopted for the past 12 months.

\begin{tabular}{|c|c|c|c|c|}
\hline \multirow[t]{2}{*}{ Technology } & \multicolumn{4}{|c|}{$\operatorname{Sign}(\mathrm{V})$} \\
\hline & Tested & Adopted & $\begin{array}{l}\text { Applied } \\
\text { now }\end{array}$ & $\begin{array}{l}\text { Applied in the } \\
\text { upcoming } \\
\text { planting } \\
\text { season }\end{array}$ \\
\hline $\begin{array}{l}\text { 1. Use of superior seeds without genetic } \\
\text { engineering (organic), and superior } \\
\text { commercial seeds (conventional). }\end{array}$ & & & & \\
\hline $\begin{array}{l}\text { 2. Seedling and sorting of seeds before } \\
\text { moving to the field, especially for small } \\
\text { fruiting plants such as mustard greens, } \\
\text { tomatoes, and eggplants. Whereas, for } \\
\text { large fruiting plants such as cucumber, } \\
\text { long beans, and beans, can be planted } \\
\text { directly. }\end{array}$ & & & & \\
\hline $\begin{array}{l}\text { 3. Use of mulch for plants such as } \\
\text { tomatoes, eggplants, and beans. }\end{array}$ & & & & \\
\hline 4. $\quad$ Use of roofed shade. & & & & \\
\hline $\begin{array}{l}\text { 5. Making beds with a width of } 100-120 \\
\mathrm{~cm} \text { and a height of } 30 \mathrm{~cm} \text {. }\end{array}$ & & & & \\
\hline $\begin{array}{l}\text { 6. The land is cultivated by hoeed or } \\
\text { plowed to a depth of } 30-40 \mathrm{~cm} \text {. }\end{array}$ & & & & \\
\hline $\begin{array}{l}\text { 7. The provision of manure is } 2-3 \text { tons per } \\
1000 \text { square meters for organic farming, } \\
\text { and around } 1.5-3 \text { tons per hectare for } \\
\text { conventional farming. }\end{array}$ & & & & \\
\hline $\begin{array}{l}\text { 8. Recommended plant spacing according } \\
\text { to each type of vegetable crop. }\end{array}$ & & & & \\
\hline $\begin{array}{l}\text { 9. Supplementary fertilization according to } \\
\text { recommendation, namely the provision } \\
\text { of manure, urine or other organic } \\
\text { material (organic), and fertilizer } \\
\text { application according } \\
\text { recommendations per plant. }\end{array}$ & & & & \\
\hline 10. Crop rotation. & & & & \\
\hline 11. Irrigation and watering management. & & & & \\
\hline $\begin{array}{l}\text { 12. Mechanical and organic pest and disease } \\
\text { control (organic farming), and according } \\
\text { to the principle of Integrated Pest } \\
\text { Mangement (conventional farming). }\end{array}$ & & & & \\
\hline $\begin{array}{l}\text { 13. Yields are placed in shaded places and } \\
\text { treated with care. }\end{array}$ & & & & \\
\hline 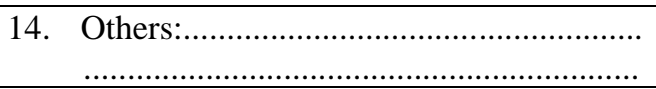 & & & & \\
\hline
\end{tabular}

4. How many times have you discussed farming problems with the following actors:

\begin{tabular}{|l|l|}
\hline \multicolumn{1}{|c|}{ Actor } & \multicolumn{1}{|c|}{ Frequency of farming problems discussion } \\
\hline Farmer & \\
\hline Extension officer & \\
\hline District agricultural officer & \\
\hline Researcher & \\
\hline Other (specify) & \\
\hline
\end{tabular}

\section{d) Knowledge sharing capability}


Have you ever provided information on technology or methods to other farmers for the past 12 months? $\square$ Yes, if yes please fill in the table below. $\square$ No.

\begin{tabular}{|c|l|}
\hline Teknology & Number of farmers \\
\hline & \\
\hline & \\
\hline & \\
\hline
\end{tabular}

\section{e) Knowledge transfer capability}

Have you ever received information on technology or methods from other partiesor the past 12 months? $\square$ Yes, if yes please fill in the table below. $\square$ No.

\begin{tabular}{|l|l|l|l|l|l|}
\hline \multirow{2}{*}{ Technology } & \multicolumn{5}{|c|}{ Sources (Sign V) } \\
\cline { 2 - 6 } & Farmers & $\begin{array}{l}\text { Extension } \\
\text { officer }\end{array}$ & $\begin{array}{l}\text { District } \\
\text { agricultural } \\
\text { officer }\end{array}$ & Researcher & Other \\
\hline & & & & & \\
\hline & & & & & \\
\hline & & & & & \\
\hline
\end{tabular}

\section{f) Functioning feedback mechanism}

How many times have you interacted with farmers, extension, related agencies, or researchers, in a community that discussed farming production for the past 12 months? meeting time. 